This item was submitted to Loughborough's Research Repository by the author.

Items in Figshare are protected by copyright, with all rights reserved, unless otherwise indicated.

"But One Needs to Work!": neoliberal citizenship, work-based immigrant integration, and post-socialist subjectivities in Berlin-Marzahn

PLEASE CITE THE PUBLISHED VERSION

http://dx.doi.org/10.1111/j.1467-8330.2012.01050.x

PUBLISHER

Wiley (@ the author; @ Antipode Foundation Ltd.)

VERSION

AM (Accepted Manuscript)

LICENCE

CC BY-NC-ND 4.0

REPOSITORY RECORD

Matejskova, Tatiana. 2019. “"but One Needs to Work!": Neoliberal Citizenship, Work-based Immigrant Integration, and Post-socialist Subjectivities in Berlin-marzahn". figshare. https://hdl.handle.net/2134/12988. 
This item was submitted to Loughborough's Institutional Repository (https://dspace.lboro.ac.uk/) by the author and is made available under the following Creative Commons Licence conditions.

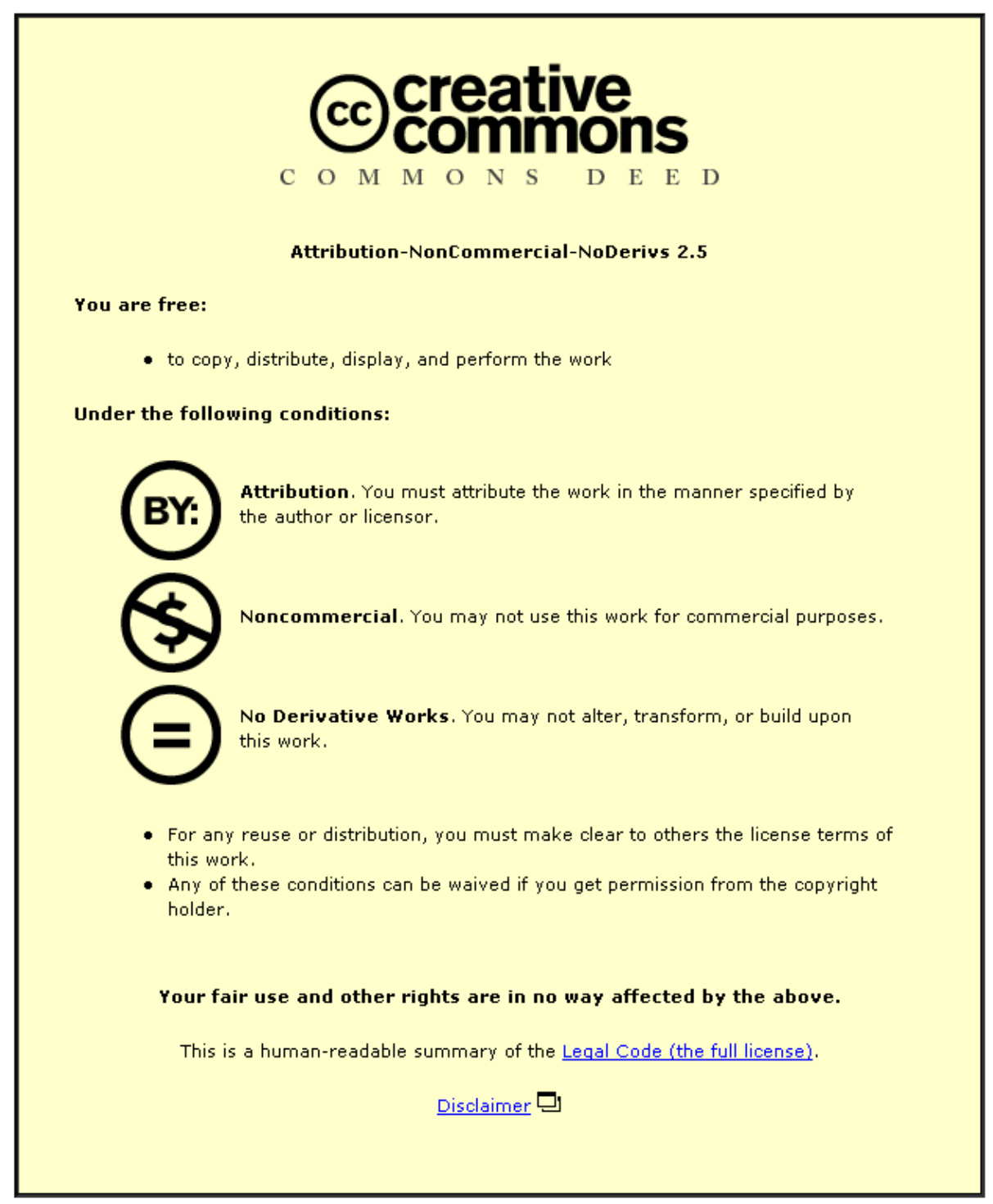

For the full text of this licence, please go to: http://creativecommons.org/licenses/by-nc-nd/2.5/ 


\author{
Tatiana Matejskova \\ Department of Sociology and Social Anthropology \\ Central European University \\ Budapest, Hungary \\ matejskovat@ceu.hu or mate0033@umn.edu
}

\title{
“But One Needs to Work!”: Neoliberal Citizenship, Work-Based Immigrant Integration and Post-Socialist Subjectivities in Berlin-Marzahn*
}

(Forthcoming in Antipode 45:4)

*This research was supported by the Doctoral Dissertation Improvement Grant \# 0726769 from the National Science Foundation as well as by the Graduate Research Partnership Program grant and Hella Mears Graduate Fellowship from the University of Minnesota. I would like to thank the editor and the reviewers for their helpful and thoughtful comments. And finally, I would also like to thank my informants in Berlin-Marzahn for their generous sharing of their experiences, without which this research would not be possible. 


\begin{abstract}
This paper examines how middle-aged and older post-Soviet immigrants in eastern Berlin navigate the neoliberalized landscape of work-based integration in face of their long-term unemployment. I first show how these immigrants' own insistence on the centrality of paid work for their feeling integrated contributes to their experience of collective despondency and enrollment in exploitative quasi-markets, including workfare. Focusing on this insistence, I examine how it draws strength primarily from their continued subscription to the conceptions of self as deeply socially embedded, and of work as a practice of such an embedding, adopted through their Soviet-era socialization into the culture of dispersed personhood and obligation to work, rather than from their adoption of neoliberal concepts of citizenship in Germany. Contributing to geographies of postsocialist experience of neoliberalized regimes of citizenship and immigrant integration this paper thus highlights how some of the aspects of post-socialist subjectivities dovetail unexpectedly with the neoliberal project.
\end{abstract}

Keywords: immigrant integration, neoliberalism, unemployment, post-socialist subjectivity, workfare, personhood 


\section{Introduction}

I want to start somewhat unconventionally. One July day in 2007 I found myself in the company of thirty-some strangers in one of Berlin's movie theaters, ready to view German director’s Bernd Böhlich’s new feature You are not alone. The movie started with an image-less dialogue unfolding against a black screen: "Why are you only coming now? The 1 Euro job was limited to 3 months! “, we heard a man reprimand someone. "I thought...”, what sounded like a middle-aged woman started responding. Before she could finish, she was interrupted by the same man: "You have to come to us immediately after the end of the measure! That's the way the game is played, isn’t it?"،, adding, after a few mouse clicks “well, well, right now it doesn’t look good at all. You are 56...” “What?!?" jumped in the woman as she finally - and visibly much younger than 56 years old - appeared on the screen. "Born in '56", clarified the man, now in the full view sitting behind a desk and a computer, who then, sighing deeply, posed himself a question "Hmm, how do get from here to retirement?" The viewers next to me and I smiled, in a bittersweet way, at this tragic-comic scene introducing us to Böhlich’s cinematic portrayal of long-term unemployment in Germany. We understood that what was unfolding was a dialogue between a fictional representative of the country's several millions without an access to the primary labor market, Mrs Moll, and her case worker, who was implying a grim prospect of her having to somehow patch up 14 years remaining until retirement age from short stints in workfare measures, volatile, povertywage jobs in the private sector or unemployment. As is clear from this vignette, this feature was meant to give a 'human face' to the contemporary experience of long-term unemployment, namely to examine artistically the intractability of having to come to 
terms with lack of stable, well-paying jobs at a time when waged work and economic independence from the state have become decisive for the dominant conception of citizenship and belonging in a society (e.g. Baldry et al. 2007, Trudeau and Cope 2003).

This paper starts from a parallel, if academic interest in experiential aspects of joblessness as they relate to workfare subjects’ quest for acceptance and socio-political inclusion. But more specifically I investigate how a particular sub-section of the German population that finds itself under a double pressure of having to literally earn their belonging and acceptance - namely recent immigrants - navigates the tension arising from living in personal and collective landscapes of structural unemployment on the one hand, and the increased valorization of work as the basis for their integration in Germany on the other. The paper does so through a focus on the middle-aged and older post-Soviet immigrants of German descent, the so-called Aussiedler (resettler/repatriate), settled over the past fifteen years in socio-economically disadvantaged neighborhoods of BerlinMarzahn, coincidentally also the setting for the movie I opened with. Unlike in the past, the post-1989 Aussiedler have been increasingly treated by the German state and the public as other immigrants who have to gain their acceptance within the new framework of work-based belonging rather than have it guaranteed thanks to their shared ethnic ancestry ${ }^{\mathrm{i}}$. In focusing on immigrants socialized in a state-socialist regime this paper considers specifically the trajectories of post-socialist subjectivities, and in particular the role and meaning of work for such subjects’ conceptions of belonging.

The paper starts with a brief overview situating the issue of immigrant integration within geographies of the ascent of neoliberal citizenship and workfarism in latecapitalist societies, including in Germany, as well as those of post-socialist 
transformations of experiences and lansdscapes of work. After an outline of the research setting and methodology that this paper draws from, I first portray the main experiential impacts of joblessness amongst post-Soviet immigrants. Subsequently I chart out how immigrants' understanding of the predicament of joblessness as precluding their integration is influenced by the legacies of Soviet-era notions of the relationship between the self, work, and the collective. Next I briefly consider why these migrants' experiences might differ from those of other post-socialist subjects in eastern Berlin, namely former citizens of the German Democratic Republic (GDR). In the conclusion I reflect on how subjectivities constructed in political economic regimes usually considered diametrically opposed, dovetail with the neoliberal project itself and the implications this has for politics of integration and belonging.

\section{Immigrant integration, neoliberalized citizenship and post-socialist geographies of} work

Despite the transnational turn challenging the bias of methodological nationalism in migration scholarship by stressing cross-border nature of contemporary migrant lives, most contemporary migrants continue to create attachments to their places of settlement and strive for inclusion also in these places (Ehrkamp 2005). As such, they remain deeply affected by the regimes of citizenship and belonging in the countries of destination. As many migration geographers have stressed, these have over the past decade, including in Germany, become marked by concomitant denouncements of multiculturalism, questioning of the compatibility of cultural and religious immigrant difference and reinvigorated calls for "social cohesion" as in Great Britain or greater immigrant “integration”, as has been the case in Germany (e.g. Phillips 2006, Phillips, Davis and 
Ratcliffe 2007). This integrationist turn has been then underwritten by what many perceive as neonationalist conservative sentiments. While insightful, such analyses at the same time remain incomplete due to their culturalist bias, or a failure to consider explicitly also political economic underpinnings of this unfolding integrationist turn.

So far the consideration of neoliberalization and marketization of citizenship has entered more political geographers' analyses of politics of immigration regulating the conditions of entry for new migrants to be, rather than migration geographers' accounts of everyday belonging. The former have thus for example stressed states' easing of legal entry and access to social and economic rights for the affluent and highly-educated professional migrants while raising barriers for the working class and/or poorly-educated subjects lacking human and other types of capital deemed crucial for contributing to capital accumulation without posing a potential risk of needing state support (e.g. Sparke 2006, Nevins 2007). Germany has not been an exception from this trend. The country has, on the one hand, introduced an investor immigrant category. On the other, it has ushered in new obstacles for other immigrants, requiring for example all immigrant visa applicants from poor and middle-income countries, including those joining their spouses already living in Germany, to prove basic German skills. It is telling that only academics, other professionals and college graduates are exempt from this seemingly innocuous immigration prerequisite.

The importance of this economistic optic of immigration, most obvious in Germany during the negotiations about the new immigration law (Bauder 2008), has become also a structuring principle behind the renewed state interest in immigrant integration policy (for Holland see e.g. Schinkel and van Houdt 2010). In contrast to the 
past when labor market integration was certainly deemed important for societal integration (Hunger and Thränhardt 2001), immigrants’ paid employment and economic self-sufficiency have become "an indicator of successful integration” in their own right by now (Die Beauftragte der Bundesregierung für Migration and 2009: 13). The centrality of stable employment is conceptualized explicitly as such also in the official state documents (see Figure 1). Moreover, some of the new measures, such as making the emblematic "integration courses" obligatory for unemployed migrants already residing in the country long-term, betray the subscription of integration policy to the neoliberal logic (see also Bommes 2006).

\section{[Insert Figure 1]}

The ongoing erosion of legal, rights-based equality, or conditions of formal citizenship, for different types of migrants forms, however, only one aspect of marketbased stratification of citizenship. It is also intertwined with cultural citizenship, or popular discourses about who counts as a worthy and acceptable immigrant (cite). Working class migrants’ poorer education or lower skills position them often as easily replaceable and disposable subjects (e.g. Hiemstra 2010), even if the inclusion of elite migrants, especially those easily racialized, does not unfold unproblematically (Mitchell 2004). Still, even the former can at times be also morally recuperated as worthy-enough subjects through discourses of their industriousness. The un- and under-employed dependent on welfare, however, constitute the antithesis of the neoliberal matrix of citizenship ideal of a self-governing subject achieving not only economic independence from the state, but also, in the highest order, always maximizing her economic potential (Rose 1999, England and Ward 2007, Davidson 2008). In Germany it is precisely these 
migrants that the state frames as having the direst "need of integration"ii; unlike those already contributing to the national economy, as avidly portrayed for example in nationwide integration campaigns (Figure 2\&3). In the long run then, the country’s new integration policy seeks to prevent or minimize the establishment of state-dependent migrant class by putting a disproportionate focus on two areas deemed to be the key obstacles for labor market integration, namely low educational qualifications and inadequate levels of German language fluency amongst immigrant children (FRG 2007). It the meantime however, elderly unemployed and under-employed migrant residents, like those that this paper focuses on, are left struggling with their position as antithetical citizen subjects.

\section{[Insert Figure 2 \& 3]}

This paper's focus on migrants as workfare subjects thus situates it within geographic work on workfarism, a theme long at the center of critical geographers’ inquiry of neoliberalization processes. As has been widely documented, the shift towards post-welfare states has been accompanied by a rise to dominance of a highly individuating moralistic discourse representing structural unemployment as a behavioral problem of inflexible and work-resistant welfare recipients (e.g. Peck and Theodore 2000, Theodore 2007, Ehrke 1999). While such an imaginary of welfare subjects has been empirically refuted (Leonard 1998, McDowell 2003), it nonetheless often continues to be reinforced through particular practices of local governance and training projects for welfare-recipients (Haylett 2003). Such practices are certainly shaped by local political and cultural contexts, resulting, as geographers have stressed, in regionally uneven workfare landscapes (MacLeavy 2008). Still, the adoption of post-welfare strategies has 
been uneven also at the national scale. Germany has especially tended to be thought of as somewhat of a 'laggard' behind the United States or the UK in moving from welfare to workfare (Ludwig-Mayerhofer and Wroblewski 2004). But as German scholarship has emphasized, with the implementation of the so-called Hartz commission reforms of 2002 and their expansion in 2005 the German state has in fact adopted "work-first” perspective and moved decidedly towards getting welfare recipients to work "at any price" (Eick 2003: 57), see also (Wohlfahrt 2003) ${ }^{\text {iii }}$. Workfare measure of " 1 Euro job" iv and the institution of JobCenters ${ }^{v}$ that we encountered in the opening vignette are only two, if most visible and widespread technologies of Germany's workfarist citizenship, which makes its (especially) social benefits conditional on one's participation in workfare measures or poverty jobs (Handler 2003). While the existing analytical and topical research foci on workfare have contributed to critical understanding of workfarist regimes, the perspective of labor market regulation (Peck 2001) and focus on institutional contexts dominating this research have left other, especially experiential aspects of workfarism somewhat neglected. In particular, arguably little attention has been paid to everyday experiences of changing access to and nature of work as well as "worklessness" (but see e.g. Jones 2008, Pratt and Jarvis 2006 on the former).

Such socio-cultural aspects of transformations of landscapes of work have formed, on the other hand, a strong agenda within post-socialist geographies. This is due in part to particularly dramatic changes in the countries of the former "Eastern block". Through the introduction of post-Fordist workplace practices these have ushered in new experiences of work-related anxieties arising from capitalist pressures to increase labor productivity, greater salary differentiation and diversification of work hours (Hardy and 
Stenning 2002, Stenning 2005a). In conjunction with the competition for ever scarcer jobs and a novel threat of long-term unemployment such tensions have been documented to have had destructive impacts on interpersonal and often communal relations.

Regardless of certain "economic and social decentring of work" these profound changes have then ensured that the realm of work continues to thoroughly permeate personal lifeworlds in post-socialist Europe (Stenning 2005a: 252). Spatially-minded research has further focused on shrinking of everyday geographies of specifically unemployed postsocialist subjects, increasingly limited to close neighborhood circles and dependent on highly localized social capital and networks (Stenning 2005b, Smith et al. 2008, Smith and Stenning 2006). Withdrawal to the private sphere of home (van Hoven 2004, Smith 2000) has in conjunction with sudden feelings of uselessness brought about also a sense of radical displacement and societal exclusion for the long-term unemployed (Hörschelmann and van Hoven 2003). This scholarship has thus started to heed a recent call (Stenning 2008) for extending geographies of work beyond the workplace and more towards social contexts and meanings of work, a trajectory this paper seeks to contribute to.

\section{Research Setting}

In order to do so, this paper focuses on Berlin's northeastern locality of Marzahn (see Figure 4 for the map), once the largest estate in the former German Democratic Republic (GDR), which housed almost 200,000 people in its heyday in the late 1980s (Hübner et al 1999). Before 1989 it was a coveted residential address, owing to the provision of modern facilities such as more spacious apartments, central heating and green spaces unavailable in the derelict central city areas. After the fall of the wall 
Marzahn, like many other socialist-era housing estates, acquired very quickly a negative public image (Kil and Silver 2006). Due to in part high concentration of impoverished population in the district, itself partially a result of the outmigration of better-off residents since the mid-1990s, Marzahn has by now become close to a nation-wide emblem of a home for 'losers' of unification and neoliberal transformation (Matejskova forthcoming)Central and especially northern areas of Marzahn, which this research focused on, have been affected particularly strongly by the population decline, unemployment and dependence on welfare. Thus for example, in northern Marzahn the population loss amounted to 35\% between 1995 and 2002, after which the population level more or less stabilized (Augustin 2012). By 2009 42\% of the population under 65 were dependent on welfare benefits for long-term unemployed and those in poverty-wage jobs (the so-called Hartz IV subjects) ${ }^{\mathrm{vi}}$, while $17.2 \%$ were unemployed (Augustin 2010) ${ }^{\mathrm{vii}}$. Marzahn is, in brief, one of the prime examples of severe landscapes of structural unemployment across the former GDR.

Its demographic shrinkage would have been even steeper if not for the settlement of large numbers of immigrants, including former Vietnamese guestworkers. But it was the settlement of over 20,000 Aussiedler that has been most palpable. In total over 3 millions of these Russian-speaking Aussiedler and their family members have arrived in Germany since 1988/89. Although most of them were resettled in the areas of former West Germany, Marzahn has over the past 15 years become home of the largest settlement of Aussiedler in the former East Germany. Today Aussiedler make up between 9 and 12.8\% of the local population in northern and central Marzahn respectively (Augustin 2012). Like most other migrant groups, they suffer from unemployment rates about twice as 
high as local Germans (Haupt and Wockenfuss 2007) ${ }^{\text {viii }}$, resulting in part from a combination of the absence of official recognition of their qualifications and insufficient German language skills.

In response to these hardships, as well as the perceived social isolation of Aussiedler and increased tensions with local residents, during the past 10 years various local community centers and non-profit organizations established a number of immigrant integration projects. They offer a wide gamut of services and activities, ranging from individual assistance with the state bureaucracy, German and Russian language courses, to retraining courses, and especially social and cultural activities. They are housed primarily within larger community centers, which often provide temporary workfare positions for long-term unemployed migrant and non-migrant residents, such as 1 Euro jobs.

\section{Methodology}

This paper draws on field research conducted during 8 months in 2007 for a project on practices of immigrant integration projects and conceptions of integration espoused by practitioners as well as by residents of Marzahn. While the broader project set out to examine the role of cultural differences and their negotiation, issues of work, workfare and unemployment and their relation to belonging in post-migration context continued to saturate everyday conversations in the field. This paper is then informed first and foremost by the ethnographic component of this research, anchored through a part-time volunteering in two integration projects in northern and central Marzahn, namely Meridian housed in Plattenverbund Kiezhaus and Kieztreff Interkulturell respectively. Such an institutional presence allowed for everyday participant observation of and 
informal conversations with Aussiedler visitors as well as staff. My regular participation at a variety of integration-related events, neighborhood gatherings and meetings of migrant and resident councils provided additional opportunities for ethnographic engagement with Aussiedler as well as local residents ${ }^{\mathrm{ix}}$ and practitioners. Additionally, in constructing my argument I draw on the information gained through formal interviews, such as some of the 27 in-depth local practitioner and politician interviews, of both local and migrant origin, and especially on four focus groups conducted with 28 middle-aged and older Aussiedler ${ }^{x}$. While these focus groups included several of the Kiezhaus's Aussiedler staff, most participants were recruited through flyers distributed in commercial and public spaces of Marzahn. Each group discussion lasted about 1.5 hours, took place in the main communal room of the Kiezhaus and was conducted in the Russian language by a trained research assistant, a native speaker of Russian ${ }^{\mathrm{xi}}$. The last section of the paper draws on two focus groups conducted with 15 middle-aged and older local Germans.

\section{Experiencing Unemployment: Despondency and Quasi-Labor Markets}

It is one thing to be abstractly aware of the issues of structural unemployment and quite another to experience its strongly palpable everyday impacts, especially the despondency it produces, in the proverbial field. I would thus like to commence with a brief vignette. It was at one of the local institutions-cum-integration projects in Marzahn, the German-Russian Tchechow theater, that I encountered one of the first Aussiedler. As I sat down to a table to wait for a meeting with the manager of this communal theater I noticed right away a woman across the table. Slouching in her chair, with her head resting heavily in her right hand, she stared outside through the glass wall. The woman 
was, however, not observing the life on the street. Hers was a stare devoid of any interest in what was going on around her. As she finally felt my own gaze upon her, she slowly turned her head towards me. Hesitating to disturb her from her visible discomfort, I haltingly attempted a conversation. Her name was Marina ${ }^{\text {xii }}$, an Aussiedler from Kazakhstan. She came to ask the theater manager, herself an immigrant, whether she might have a 1 Euro job for her. It was not much of a conversation, however. Marina, somewhere in her late 40s, was only interested in sharing with me, and even then only half-heartedly, her despair of not being able to find work. She would utter a few words, subsequently turn her head away to stare vacantly outside the window in the same direction and with the same resigned expression as before, and then slowly return to me after a minute or two with a few other quietly-spoken words or sentences. Even when she was talking, her face was almost devoid of any movement. Yet I could almost see the wrinkles on her face get deeper. "There’s no work”, she repeated over and over, switching between Russian and German.

If I venture into this ethnographic detail, it is only to give a sense of the despair over unemployment pervasive in Marzahn. While for some observers the lack of Aussiedlers' acceptance as Germans is the most defining feature of their settlement in Germany (Pfetsch 1999), in Marzahn the pain of life without work has surpassed this disappointment. The former bears after all some resemblance to their often less-thancomplete acceptance as 'Germans' in the Soviet Union. Life without work, however, presents a complete rupture with their Soviet lifeworlds.

Despondency of unemployment has etched itself onto the bodies of many Aussiedler, making them, as many noted, look older, visibly worried and walk around in a slouched, 
defeated way. But most of the Aussiedler tended to point out especially the psychological impacts of un- and under-employment. Being out of work was perceived as dangerous, contributing to alcoholism and frequent break-ups of families. These narratives of despondency over unemployment were, however, not necessarily personal stories of any one informant. Rather, just like the pervasive dictum of "there's no work" - for us, the middle-aged, the Aussiedler - suggests, the 'end of work' situation in Marzahn was perceived as afflicting the whole community.

Middle-aged and older migrants often attempted to mitigate this despair by seeking out any kinds of work. As Lara put it:

I try to help my compatriots to integrate here, to find work. But that's absurd, I couldn't even find work for myself, I'm doing it as a volunteer. If you don't want to suffer from depression, to become despondent, you agree to any kind of work, even volunteering. I'm hoping something comes out of it, for sure. (Lara, F, 50-60)

The importance of finding at least some "small job” has facilitated these migrants' enrollment into exploitative quasi-labor markets, or labor-markets that do not provide jobs with living wages. While welfare subjects have been increasingly imagined in Germany as participating only reluctantly in the so-called secondary labor market of workfare measures, Marina whom we encountered earlier, was hardly an exception. Workless Aussiedler inquiring about a 1 Euro-job were a daily occurrence in the two projects where I volunteered. In the larger one, Meridian, almost half of the thirteens migrant 1 Euro-jobbers there had sought out these positions themselves.

Such middle-aged Aussiedler sought out employment also in the minimum wage jobs in the private sector and as volunteers. Eager to criticize lack of appropriately paid employment, some community leaders, such as Ms Köhler from the project ZusammenLEBEN (Co-existence), referred to such employment respectively as "tertiary 
and quaternary labor markets”. It might seem a stretch to refer especially to volunteering as a labor-market activity. Yet volunteering has been increasingly ideologically connected to paid work. As in the case of workfare jobs, politicians have been promoting volunteering as an opportunity for gaining new skills and for (re)instilling work ethic into the long-term unemployed (Hardill and Baines 2009). Even though volunteering in reality rarely enables a successful transition to paid work (Baines and Hardill 2008),many volunteers continue to engage in it at least in part out of such a hope, as evident from Lara's quote above. As such, voluntary work effectively functions as an alternative to the (primary) labor market, as for those without a job it can entail similar work-hours. Many in Marzahn, like Katharina from Kiezhaus, ended up continuously floating between these different quasi-markets. An Aussiedler woman in her early fifties and a teacher with 24 years of experience from Russia, she struggled in Germany, volunteering full-time running a pottery club in the Kiezhaus before securing a 1 Euro job for another half-ayear there, only to resort afterwards to underpaid cleaning jobs while volunteering twenty hours a week in a local church, hoping to secure yet another 1 Euro job there. As this shows, the post-socialist situation of slipping from "one low-paid, insecure job to another, to periods without work, and back again” (Smith et al. 2008: 296) gets further exacerbated by working poors' engagement in long-term, unpaid volunteering, promoted as a component of neoliberal citizenship.

\section{Aussiedler and Workfarist Discourse}

The eagerness of middle-aged and older Aussiedler in Marzahn to find any kind of job did not seem to have been driven primarily by material dissatisfactions. During one focus group Boris (M, 30-40) for example asserted, “There’s enough money. You can 
really live on what [the state] gives you here. You can even save some to go on a vacation”. Especially migrants from rural areas often commented on how their housing in Germany was of high quality with electricity and heating steady, and how their "fridge is always full”. In another focus group Aussiedler even mocked a TV feature for criticizing how local German welfare recipients could not survive anymore on their benefits. Like Boris above, they jovially concluded that they, the Aussiedler, could even save for a summer beach vacation while on welfare. In many casual conversations, too, older Aussiedler assessed welfare in Germany as generous, and a few of them even characterized the state as overly indulgent. Their vernacular discourse about welfare thus at times resembled that of the federal state.

In a similar way, my informants tended to insist on their inability to achieve integration and feel like they belonged in Germany unless they held a job. As Viktorya, an Aussiedler woman in her fifties put it: "[To be jobless] is to be good for nothing, to remain unfulfilled and unacknowledged. It is as if you weren't a member of a society, you're like a foreign element”. Alexander, an Aussiedler man, also in his fifties, was even more explicit: “To feel integrated one needs to feel like he’s a full person. And that's not about one's nationality. It's about work. It doesn't matter what kind”.

Integration practitioners in Marzahn might have reinforced this idea that integration can be achieved only or primarily through work. Especially project leaders of immigrant origin shared this view, as expressed by Ms Forner, the head of Club Dialog: “People can't become integrated without work. That is my deepest conviction”. Some of them, like Ms Hayduk, head of the Aussiedler association Aussiedler Forum and one of the leaders of the project Aussiedler orientieren Aussiedler (AOA), urged their fellow 
migrants to redouble their efforts to find work or volunteer so as to regain their selfesteem. Non-migrant practitioners also stressed the importance of employment for integration, even if their rationale rested more on the traditional conceptualization of workplace as providing space for a guaranteed engagement with local Germans. Overall then, the views of the local practitioners betrayed a more social understanding of the role of work in the integration process, rather than a more strictly economistic one, prevailing at the national scale. More importantly, almost all the experts in Marzahn - a district where almost half of the votes in the last parliamentary elections were cast for Die Linke, the former party of democratic socialism, PDS - expressed their strong opposition to the federal neoliberal agenda. Thus, while local practitioners' emphasis on work has certainly had some impact on Aussiedlers' perception of the intertwinement of work and integration, I suggest that such discourses have in the very first place found a fertile ground to build on amongst post-socialist middle-aged immigrants. As I elaborate next, this ground consists in these migrants' continuous espousal of Soviet-era conceptions of personhood built on co-dependency of work contributions, sense of self and belonging in the society.

\section{The After-life of Soviet-era Conceptions of Work, Self and Society}

Maybe our children will be different and it won't be all about work for them....Life is not only about being unemployed, one can arrange it differently, for example without work. But we were raised so that one has to have work. (Sveta, F, 50-60)

The long-term unemployment that Aussiedler have experienced in Germany represents a challenge for their sense of belonging there. Soviet-era socialization brought for many of these older subjects an internalization of an obligation to hold a job. Twenty years later in Marzahn they continued to talk about the state of being a worker as something "natural". Ms Hayduk, one of the community leaders even asserted that 
Aussiedler "love to work". As a representative of local Aussiedler she might have wanted to portray her community in the best possible light to me, an outsider. But other migrants' ruminations about their despondency revealed the centrality of work experience for their sense of self more broadly, and especially for their generation, as evident in Sveta's quote above.

Many Aussiedler described their situation of not earning their own money as degrading and unbearable, or, as Boris (M, 30-40) put it: "It crushes you. It's oppressive”. In discussions some additionally evoked their friends or acquaintances as having become allegedly so ashamed that they had chosen not to claim all the benefits they were entitled to. On the one hand, such articulations recall neoliberal stigmatization of welfare-dependence. On the other, they also draw on a persistence of Soviet-era relationship to work amongst this older generation. State-socialist regimes namely fostered the idea of personhood as related to work through the practice of reciprocity between the state and its subjects (Dunn 2004). While the state had to provide jobs and benefits to its citizens, they had to provide labor in return for wages and other benefits. Being continuously unemployed in Germany thwarts Marzahn’s Aussiedler fulfillment of what many accepted as their side of the social contract with the state.

Still, there is a much more fundamental aspect to Aussiedlers' embrace of centrality of work beyond just its groundedness in this regime of reciprocity. Namely work had been tied to their conception of themselves as subjects deeply embedded in a social collective. In the most rudimentary way, it is primarily through work that Aussiedlers' sociality was nurtured. Using a common Russian term denoting something akin to an everyday practice of being with others in togetherness (Yurchak 2005), Olga 
(F, 40-50) concluded this part of a group discussion by stating, with a vigorous confirmation by her peers, "Work gives one obshchenie” ${ }^{\text {xiii. }}$. In state-socialism, where jobs tended to be long-term, if not life-long, the workplace was the main site for organizing social activities, becoming effectively a basic unit in which everyday life was grounded (Stenning 2003). Women in particular perceived workplace community as a "vital source of emotional support" (Ashwin 1999: 252) and a social focus different from home. This companionship aspect of paid work might have been most important for women in part also because their work tended to be more group-based and connected to services, such as kindergartens or shops.

The importance of work as a site of "communal sociability” (Ashwin 1998:192) became palpable particularly strongly during my volunteering in Meridian. Although the thirteen Aussiedler women bemoaned at times the transient nature of their collective, they highlighted how beneficial it was for them to engage with others, share their experiences and hardships and provide each other with support. One of them, Galina (F, 50-60), even claimed that being with others outside of her family during her 13-month 1 Euro job made her finally feel "completely healthy” after having been sick for five years while she was out of work. Six weeks long catering training program that three of these women were eligible for during my field research brought about an additional sense of satisfaction. But it was not because they saw the training as particularly useful. Rather, as Zora (F, 40-50) concluded, they enjoyed the experience because they got an opportunity to meet other trainees and cultivate relations with them. In Meridian itself such a cultivation of relations was also a crucial part of the everyday. It unfolded through casual conversations conducted while performing a certain task or during mundane social 
activities, such as sharing of home-brought lunch around the table, and celebrations of everyone's birthdays and namedays, building social relations that extended in many cases beyond the workplace ${ }^{\mathrm{xiv}}$. Importantly, these were not just activities women spent time on when there was nothing to do. Rather, set times were devoted to communal lunches or afternoon tea and pastry times, times that the women observed almost religiously. That similar social practices and events were held onto even in bankrupt collective enterprises in post-socialist Russia rather than be abandoned to cut costs, reveals their utmost importance as embodying and enabling “an intense life precisely "in society”” (Humphrey 2002:174).

The weight Humphrey gives to the intensity of social embedding as conceived and practiced in the Soviet society is not coincidental. Conceptions of sociality, in a sense of a specific way the relationship between the self and the society is configured and lived in the everyday, differ in different systems of personhood (Dunn 2004). Middle-aged and older Aussiedlers' understanding of themselves as profoundly socially embedded rather than individualized subjects drew especially on state-socialist constructions of subject. Self was understood here as arising through an intense cultivation of social ties with others, through a cultivation of some collective. In state-socialist regimes more broadly, and in its Soviet mode in particular, human existence was conceptualized vigorously through the idea of a collective, especially a collective bound through labor. In the Soviet ideology the nation was after all conceived of primarily as a community of workers writ large rather than that of ethno-nationally homologous subjects. The labor collective was then a " particularly hallowed form of kollektiv; it was a concept with spiritual, moral and mythical dimensions” (Ashwin 1998:192) ${ }^{\mathrm{xv}}$. Even if workers’ understandings of a 
collective differed from the meanings ascribed to it by the official, state version, workplace-based collective was a site of "genuine attachment" (ibid). And the intimate connection between the self and the collective was effectuated in a most immediate way through giving labor. Working became what makes one human, an idea that strongly resonated amongst middle-aged and older Aussiedler in Marzahn: "When you work you feel..”, started Nora (F, 50-60) in one focus group, “yes, simply a human”, with Marina (F, 40-50) completing her sentence. "Exactly. A human”, Alexander (M, 40-50) concurred.

This effective conflation of being, in a sense of becoming human, and work, is reminiscent of the blurring of the divide between what one is and what one does that liberal and even more so neoliberal governmentality has fostered (Dunn 2004). Yet, to draw here on Elizabeth Dunn's work (2004), such a blurring between being and working unfolds differently in liberal and socialist regimes of personhood. The (neo)liberalized self is more heavily individualized and its personal identity becomes increasingly derived from her position within a particular section of the labor market, that is her professional, work-related identity. That self itself is imagined as composed of a sum of increasingly easily identifiable and parsed out internal skills and capabilities to be deployed in the work process, and corresponding to a specific, seemingly natural exchange value. For liberal subject the equivalence is then drawn between one's identity and the type of work one does. For the state-socialist subject on the other hand the relationship between work and self was both broader and more immediate because it was not tied as much to a particular content of labor as to the process of giving labor itself. Certainly, socialist workers might have often lacked work fulfillment or not have been highly efficient. Yet, 
such points are of little relevance here since my focus is on the importance of an overarching identity as a worker-citizen within the society of worker-citizens. The entanglement of the self and the work became expressed through the naturalness of the very “condition of being employed” (Fehérváry 2009: 433). Crucially, the strength of this identity of a worker-citizen entered the consciousness of many an Aussiedler in Germany precisely at the moment of their inability to secure a decent stable employment.

The intimate connection between the state-socialist self and work was forged through work that work did socially. As Dunn specifies, workers’ labor in state-socialism was never fully alienable. It was never fully compensated for by the wages because labor and labor-power were not thought of as a commodity. Work produced a remainder because socialist workers tended to see their labor as a valuable part of a socially embedded personhood through which they created, to cite Dunn, “an enduring relation to co-producers” (Dunn 2004: 128). The person was constructed not just through, but in work because non-objectified labor was a practice of social embedding, of connecting up to others and thus of a constant co-constitution of a social collective without which one is not. In other words, work tended to exceed labor in its sociality. This is where work joins obshchenie, which is "far more than communication between separate individuals; it produced a form of sociality and a form of personhood that transcended the personal and the social” (Yurchak 2005:151). In the late capitalist conjuncture work has, however, become circumscribed much more thoroughly by labor by, in part, having shed its cohesive sociality. As Russian workers of one Westerner-privatized post-socialist enterprise suggested, they now needed a therapist because they had to work for money 
rather than for their "soulfulness", or their connectedness with others (ChamberlainCreanga 2008) .

The meaning of work as a construction of self through the physical and spiritual sustenance of a collective would also extend also to non-paid work. I suggest that this is why the Aussiedler in Marzahn assessed their life of hardship in the CIS as a "true living”. Female, as well as some of the male informants stressed how they would take care of their houses, cook all their meals, grow their own food, go to the woods every fall to collect mushrooms or wild berries, and make their own canned goods. As Tonya (F, 30-40) reminisced: "You had to do everything, to sow, to water the garden. You had to work 8 hours, take the kids to the kindergraten, pick them up, and so on. We lived!” Viktorya (F, 50-60) also evoked the condition of living through work: "Back there everything was about vyzhīvaemost'. One had to live!’ Vyzhīvaemost' can be crudely translated as an ability to survive. While describing life as survivalist might seem negative, for Viktorya and her peers, such a description had a strong positive connotation. Much post-socialist literature has interpreted for example home food production practices that my informants described, as a response to a lacking state provision of such goods under state-socialism, or to post-socialist austerity. Adrian Smith (2002) suggested, however, also the possibility of other, social or cultural significance of these practices (see also e.g. Thelen 2011). Aussiedlers' validation of the necessity of sociallyreproductive and especially home food-producing practices indeed pointed to a concomitantly social and self-making meaning they derived from them. Namely, one had to apply oneself through this kind of work every day in order to nurture a collective, in this case that of a family or a network of neighbors and/or friends. The Aussiedler in 
Marzahn tried to replicate this "fullness of life" (Ira, M, 50-60) by at least acquiring a garden plot in new community gardens established in lieu of razed buildings. Still their current situation in Marzahn is not comparable. Surely, one can grow produce and process it. But, as these migrants pointed out, this was pointless because they could simply purchase similar products for cheaper. Their work simply not needed anymore, their vexation grew.

Similar feelings of uselessness also drove Aussiedlers' dissatisfaction with workfare jobs that many tried to secure. As noted earlier, many were able to enjoy some aspects of 1 Euro jobs and similar positions. Yet there persisted a deep discontent with workfare because of its often too obvious "make-work" quality. In Meridian, Aussiedler women would often gloomily sit around, their heads in their hands and deplore the lack of tasks. At times they would try to come up with a task of their own to break up the boredom. On the occasion of a two-week sick leave of the project leader they for example embarked on a renovation project, carpeting the small communal room by themselves and out of their own pocket. The artificial nature of many of the workfare positions stands once more in a subtle contextual contrast to the state-socialist times. Shortage of input materials at times stalled the production in state-socialist factories, itself an impetus for floor managers to assign some non-production-related make-work measure. This was, however, a situation shared widely across the state-socialist economy. In Germany today, there is another frame of reference, another standard against which Aussiedler measure up their personal experience. Namely they pointed to the primary labor market with jobs where one's labor is in demand and valued by the society. In such an environment Aussiedler perceived themselves as third class citizens. 
Aussiedler bemoaned that their labor, resources and experiences, rather than being harnessed, were being wasted by the German state and society. In this regard many also expressed disbelief at what they saw as the German state's lack of will of the German state to provide sufficient training that could enable them to become productive citizens again. Although there were various training initiatives, most of the time they were not fully funded, as in the case of one of the local Aussiedler community leaders, Ms Hayduk. Several years back she had tried to obtain training to become a social worker for disabled children. She was informed by the local JobCenter that she was only eligible for two years of funded training and had to pay for the third year herself. During our interview at her home Ms Hayduk, stressing how hard she had fought for the reversal of that decision, even produced, distressed all anew, a letter from Chancellor Merkel's office confirming the rejection of the third-year funding. Lacking personal or family funds for the final year of the training, she eventually gave up on her effort. Other informants deplored also the ageism they had encountered when trying to pursue stateprovided retraining options. Kirill (M, 40-50) for example recounted his experience of trying to get the local JobCenter to enroll him in the training program to become a machinist: "At 43 I was old for it and there was no reason to spend money on me". "Well, that was the message", he added with resentment. Without access to work perceived as meaningful and valued by the society, middle-age and older Aussiedler then saw their lives as effectively over well before their retirement age. Or as Vera (F, 50-60) concluded: “I’m working (literally sitting on) my 1 Euro job, but nothing awaits me anymore.”

\section{Aussiedler and Other Post-Socialist Subjects}


Post-socialist geographers Kathrin Hörschelmann and Bettina van Hoven (2003)have documented a strong sense of loss and dislocation induced by the widespread long-term unemployment among post-socialist German subjects in the late 1990s (see also van Hoven 2001). In my own research in Marzahn a decade later local middle-aged and older Marzahner continued to bemoan the unavailability of decent job opportunities adequate to their education and experiences as degrading, contributing to their selfassessment as $2^{\text {nd }}$ class citizens. As evident from Heike’s (F, 50-60) summary, dependence on welfare in unified Germany troubled many: „We didn`t live badly before and unemployment was not an issue in the GDR-era. We worked hard and now we have to go begging!“

Still, locals' understanding of the predicament of unemployment differed slightly from that of their Aussiedler peers. Their despondency did not seem as palpable. More importantly and quite surprisingly, many also rejected the ideal of paid work as indispensable for integration, citing the lack of employment. We can surmise that the weakened communal sense of despair might have been a result of lower levels of unemployment in comparison to the Aussiedler, and, importantly, of a certain degree of personal and societal reconciliation with long-term unemployment as a structural feature of economy in unified Germany. Most Aussiedler in Marzahn spent a large part of the 1990s in the post-Soviet environment where a number of aspects of Soviet-era socioeconomic organization, especially more socially protective features, still persisted. For example, many a Russian, former state-managed company throughout the 1990s continued to be primarily "concerned with survival and the social protection" of its workers and "with reproducing itself as a kollektiv" rather than by profit motives 
(Humphrey 2002: 75, 80 respectively). Equally, even though these post-Soviet years were characterized by an economic collapse and declining real wages, unemployment rates were low (Round and Williams 2010). In contrast, local Marzahner were forced to start adjusting to the capitalist labor market conditions right away after the collapse of statesocialism.

Moreover, despite the fact that East Germans were also socialized in a selfdescribed "worker and farmer state”, their experience of state-socialism itself was underwritten by East Germany’s geopolitical situation as a part of a divided nation and local cultural history. East German socialism was molded by its direct and ongoing contention with the West German mode of socio-economic and political mode of organization. Along with East Germans citizens' direct exposure - through daily media and at times personal contact - to this West German alternative this ongoing contestation imparted itself onto Germans’ own lived socialism (Lüdtke 1994). Moreover, the socialist practice of "work as relationality” (Chamberlain-Creanga 2008: 24) and as obshchenie, so vital for post-Soviet Aussiedler, draws on Russian or Soviet culture of "dispersed personhood” (Yurchak 2005: 151) ${ }^{\mathrm{xvi}}$.

And last but not least, local Marzahner have also had a long recourse to a strong “oppositional political discourse” (Haylett 2003: 778) provided by The Left, heavily dominating the district. In contrast to the federal neoliberal discourse, the Left stresses the failure of the German state's obligation to provide employment opportunities, thus framing the problematic of joblessness in a diametrically opposed way. Although Marzahn's Aussiedler have started tapping into this discourse, most still shy away from any criticism of the German state due to what they perceive as a very generous settlement 
assistance they received in the past. Thus in comparison to the local Germans they remain attached to their "emotional expressions of loss" rather than raising their feelings of injury and dispossession of unemployment - through the vehicle of for example Left party - into a "political capacity" (Haylett 2003: 778).

\section{Conclusion}

Geographic scholarship examining socio-cultural developments in post-socialist contexts has firmly demonstrated "pervasive and forceful legacies of socialism" (Stenning 2005: 237). This paper echoes such a conclusion by highlighting how middleaged and older post-Soviet Aussiedlers' perception of their quest for integration in Germany as deeply thwarted by their joblessness is intimately tied to their continued espousal of the idea that paid work is indispensable for belonging, internalized during state-socialism. As subjects whose identities were built around the idea and the lifelong experience as workers among other workers, their sense of self has been thrown into disarray. Regardless of their improved material conditions in Germany, communal gloominess over long-term unemployment lingers on, intimately bound with a lacking sense of belonging in their new home.

Paid work has played a central role for subjects' integration into the society in all modern societies, aptly named societies of work by Hannah Arendt. More than just an issue of material survival, work became an important source of various social institutions as well as modern subjective identities. Still, as has been pointed out, work became invested in many aspects with an even "greater structural significance" in state-socialism through state's productivist ideology and conceptualization of society specifically as $a$ society of workers (Kohli 1994: 38). Most importantly, state-socialist persons, as 
constructed through ideology and in the everyday practice, came to perceive the meaning of work rather differently. Rather than laboring for herself, as in the case of a much more autonomously constructed liberal subject, state-socialist subject's work was directed towards a larger social collective. Work thus became lived more broadly as the mechanism through which a subject and the society became co-constituted. The failure of Marzahn's unemployed Aussiedler to reimagine themselves as valuable members of society through alternate mechanisms testifies to the hold that work has on their conception of integration in the society and their own value.

The strength of Marzahn's Aussiedlers' belief in work-based belonging draws, for example in comparison to their local peers in Marzahn, also on additional factors. While a conception of tightly intertwined spheres of work, self and the society was shared across the state-socialist space, national cultural contexts wrote themselves into specific expressions of such an understanding. Deep Catholic roots in Poland for example contributed to a strong sense of work-based solidarity (Dunn 2004). In case of postSoviet Aussiedler in Marzahn, broader Russian cultural conceptions of self as intensely embedded in a society might have further reinforced this state-socialist "moral economy of work”, or the understanding of work as primarily a social rather than an economic practice (Dunn 2004: 8). Moreover, Aussiedlers’ everyday position in Germany as immigrants, who are under double pressure to prove their worth to the society through work, might have also further solidified their pre-migration conceptions about the necessity of work.

By showing how the intractability of the tension between neoliberal Germany’s work-based belonging and the actual exclusion from the labor market is exacerbated by 
Aussiedlers' own Soviet-era socialization into work in conjunction with their immigrant status, this paper points to how particular legacies of state-socialist work experience inadvertently complement the neoliberal project. Dislodged from a political-economic context within which an obligation to work was matched by the socialist state's provision of jobs, middle-aged and older Aussiedlers' espousal of their internalized need to work in return for support facilitates their exploitation by the state-enabled market in neoliberalized Germany where they had gained a reputation as especially hardworking subjects (Bauder and Foertsch 2003). This, I suggest, shows that not only are actually existing strategies of neoliberal subject formation messy (e.g. Larner 2000), but also that neoliberal governmentality can profit from particular aspects of subjectivities fostered in what are usually thought of as rather antipodal types of regimes.

\footnotetext{
${ }^{\mathrm{i}}$ Migrants of German ancestry used to have a strongly privileged position vis-à-vis other immigrants during the second half of the $20^{\text {th }}$ century. The (West) German state in fact did not conceptualize them as migrants but rather as extra-territorial members of the national collective. Thus they were granted formal citizenship status almost automatically and were eligible to benefits on a par with native German citizens. These privileges have been, however, steadily declining since 1993 and the state and the public treat them increasingly as other immigrants.

ii This is not to deny that the issue of cultural incompatibilities of some migrants continues to be implicitly present in the German state's understanding of integration.

iii Expansion of workfare measures has been coupled with stricter implementation of the withdrawal of benefits in case of benefit recipient's rejection of any job offered by the JobCenter (provided the net salary is not lower than the benefits), regardless how overqualified she might be for the job. German state has also started subsidizing low-income jobs in a form of reduced mandatory social contributions (LudwigMayerhofer and Wroblewski 2004). At the same time, however, training and qualification schemes, previously an important and relatively generously funded component of Germany's “active labor market policies”, have become marginal (Eick 2003).

iv “ 1 Euro job” is a popular term for the workfare measure for the long-term unemployed, officially titled Work opportunities with paid additional costs (Arbeitsgelegenheit mit Mehraufwandsentschädigung). The popular term is derived from the fact that welfare recipients are during these 3-12 months-lasting, 30 hours/ week measures paid or in legal language "reimbursed" 1-2.50 Euro per hour. 1 Euro jobs have been significantly expanded since 2005.

v JobCenters are local authorities that since 2002 merge previously separate functions of employment assistance and unemployment benefit provision.

${ }^{v i}$ Around 57\% of children living in housing estates lived in Hartz IV families and the proportion of older residents living on these benefits has also increased in recent years (Augustin 2010)

vii The first number, however, does not include those receiving proper unemployment benefits (the so-called Arbeitslosengeld I) and the unemployment rate excluded those in poverty-wage employment, workfare measures and several other categories. Comparable numbers for central Marzahn and the whole
} 
administrative district of Marzahn-Hellersdorf respectively were 32.2 and $24.7 \%$ in case of welfaredependence, and 14.5 and 12.2\% in case of unemployment (Augustin 2010).

viii The last survey conducted by the district in 2007 showed unemployment rate amongst these migrants reaching 48\%. More recent data from the Federal Work Agency (Bundesagentur für Arbeit), however, do not distinguish between those with and without migration background but rather between German passport holders and foreigners with unemployment rates of $23.9 \%$ and $44.5 \%$ in 2009 for these respective groups (Augustin 2010).

ix I use the term "local" Marzahner to denote those residents of Marzahn without migration background.

${ }^{x}$ The largest proportion, $43 \%$ of Aussiedler in focus groups were between 50 and 60 years of age, with the next most represented group being those between 40 and 50 (22\%). Equally 18\% of participants were drawn from those above 60 and those between 30 and 40. About one-third had college degrees. Most Aussiedler with higher-education credentials had worked as teachers, economists, or engineers before they moved to Germany. After their move to Germany they experienced significant deskilling, such as from a construction engineer to a gardener, and were underemployed in Germany. Around third were long-term (that is longer than 6 months) unemployed or participated in temporary workfare measures at the time. Others were employed in low-paid service jobs, such as cleaning or gardening. The great majority came originally from either Russia (50 \%) or Kazakhastan (28 \%), with others originating from Kyrgyzstan, Uzbekistan, Ukraine, or Belorussia(1 - 2 participants from each). Only 18 per cent of the Aussiedler migrated from bigger cities in the former Soviet Union. Majority came either from small towns (42 \%) or villages (40\%).

${ }^{x i}$ My research assistant, Valentina Bär ,was at the time an organizer of an Aussiedler youth group in northern Marzahn and a college student at the Humboldt university. The interviews were transcribed by Tsisana Kavsadze from Gorbi Gallup International in the Republic of Georgia.

${ }^{x i i}$ Except for the names of practitioners and politicians interviewed, all other names used are pseudonyms.

xiii Russian terms are transliterated following the American Library Association and the Library of Congress romanization standards (ALA-LC).

${ }^{\text {xiv }}$ This included also an exchange of home-provided services, such as haircuts or sharing of contacts for informal earning opportunities, such as home cleaning. While this economic aspect of social relations might be interpreted functionally - as has often been the case in post-socialist scholarship - as stemming from a lack of economic resources, it does not cancel out genuine mutual affection and intimacy of these relations (Thelen 2011).

${ }^{\mathrm{xv}}$ The Soviet state did promote also certain, highly limited individualism within worker collectives in order to prevent a strong collective resistance (Ashwin 1998).

xvi This is not to present such a cultural conception and practices associated with it as somehow ahistorical. After all, as Yurchak points out, this practice of obshchenie, of aimless but intense intersubjectivity productive as well as expressive of dispersed personhood gained strengthened importance in Russia specifically in late socialism, even though it has a long historical lineage (Yurchak 2005). 


\section{References:}

Ashwin, S. (1998) Endless Patience: Explaining Soviet and Post-Soviet Social Stability Communist and Post-Communist Studies, 31, 187-198.

---. 1999. Redefining the Collective: Russian Mineworkers in Transition In Uncertain Transition: Ethnographies of Change in the Postsocialist World, eds. M. Burawoy \& K. Verdery, 245-271. Lanham, MD: Rowman and Littlefield

Augustin, M. 2010. Zur sozialen Situation in Marzahn-Hellersdorf 2009. 1-38. Bezirksamt Marzahn-Hellersdorf von Berlin. Abteilung Gesundheit, Soziales und Personal

---. 2012. Demographische Situation in Marzahn-Hellersdorf 2011. 1-45. Bezirksamt Marzahn-Hellersdorf von Berlin. Abteilung Gesundheit, Soziales und Personal

Baines, S. \& I. Hardill (2008) 'At Least I Can Do Something': The Work of Volunteering in a Community Beset by Worklessness. Social Policy and Society, 7, 307-317.

Baldry, C., P. Bain, P. Taylor, J. Hyman, D. Scholarios, A. Marks, A. Watson, K. Gilbert, G. Gall \& D. Bunzel. 2007. The meaning of work in the new economy. Palgrave Macmillan.

Bauder, H. (2008) Neoliberalism and the Economic Utility of Immigration: Media Perspectives of Germanyłs Immigration Law. Antipode, 40, 55-78.

Bauder, H. \& C. Foertsch. 2003. Integration und Ausgrenzung von Zuwanderern auf dem Berliner Arbeitsmarkt: Ergebnisse einer Umfrage. [http://ceris.metropolis.net/virtual\%20library/economic/bauder1.pdf] Toronto: CERIS Discussion Paper.

Bommes, M. 2006. Integration durch Sprache als politisches Konzept. In Paradigmenwechsel in Einwanderungsfragen? Überlegungen zum neuen Zuwanderungsgesetz, eds. U. Davy \& A. Weber, 59-87. Baden-Baden: Nomos Verlagsgesellschaft.

Chamberlain-Creanga, R. 2008. We want a psychologist!': Minorities between Money and Soul in Moldova's Global Factory. In SSRC) Inter-Asian Connections Conference. Dubai School of Government, Dubai (UAE).

Davidson, E. (2008) Marketing the self: the politics of aspiration among middle-class Silicon Valley youth. Environment And Planning A, 40, 2814-2830.

Die Beauftragte der Bundesregierung für Migration, F. u. I. \& (2009) Gutes Zusammenleben - klare Regeln.

Dunn, E. C. 2004. Privatizing Poland: Baby Food, Big Business, and the Remaking of Labor Ithaca, NY: Cornell University Press.

Ehrkamp, P. (2005) Placing Identities: Transnational Practices and Local Attachments of Turkish Immigrants in Germany. Journal of Ethnic \& Migration Studies, 31, 345364.

Ehrke, M. 1999:. Revidierter Revisionismus. Der Dritte Weg und die europäische Sozialdemokratie Bonn: Friedrich Ebert Stiftung.

Eick, V. 2003. Berlin on the ropes: Nonprofits in transition and under pressure. In »From Welfare to Work « Nonprofits and the Workfare State in Berlin and Los Angeles, eds. V. Eick, M. Mayer \& J. Sambale, 50-58. Berlin: John F. Kennedy-Institute, Free University. 
England, K. \& K. Ward. 2007. Neoliberalization: States, Networks, Peoples. WilleyBlackwell.

Fehérváry, K. (2009) Goods and states: the political logic of state-socialist material culture. Comparative Studies in Society and History, 51, 426-459.

FRG, G. o. t. 2007. Der Nationale Integrationsplan: Neue Wege - Neue Chancen Presseund Informationsamt der Bundesregierung

Handler, J. F. (2003) Social citizenship and workfare in the US and Western Europe: from status to contract. Journal Of European Social Policy, 13, 229-243.

Hardill, I. \& S. Baines (2009) Active Citizenship in Later Life: Older Volunteers in a Deprived Community in England. Professional Geographer, 61, 36-45.

Hardy, J. \& A. Stenning. 2002. Out with the old, in with the new? The changing experience of work for Polish women. In Work, Employment and Transition: Restructuring livelihoods in post-communism, eds. A. Smith, A. Rainnie \& A. Swain, 99-116. London: Routledge.

Haylett, C. (2003) Class, care, and welfare reform: reading meanings, talking feelings. Environment And Planning A, 35, 799-814.

Hiemstra, N. (2010) Immigrant "Illegality" as Neoliberal Governmentality in Leadville, Colorado. Antipode, 42, 74-102.

Hörschelmann, K. \& B. van Hoven (2003) Experiencing displacement: The transformation of women's spaces in (former) East Germany. Antipode, 35, 742760.

Humphrey, C. 2002. The unmaking of Soviet life: everyday economies after socialism. Ithaca, NY: Cornell University Press.

Hunger, U. \& D. Thränhardt. 2001. Die Berliner Integrationspolitik im Vergleich der Bundesländer. In Migration und Integration in Berlin. Wissenschaftliche Analysen und politische Perspektiven. , ed. F. Gesemann, 109-126. Opladen: Leske+Budrich

Hübner, C., M. Rank, et al. (1999). Historischer Überblick. 20 Jahre Marzahn. Geschichte Bauen - Leben. D. Ifland. Bezirksamt Marzahn von Berlin, Beziksmuseum: 7-63.

Jones, A. (2008) The rise of global work. Transactions Of The Institute Of British Geographers, 33, 12-26.

Kil, W. \& H. Silver (2006) From Kreuzberg to Marzahn: New Migrant Communities in Berlin. German Politics and Society, 81 95-121.

Kohli, M. 1994. Die DDR als Arbeitsgesellschaft? Arbeit, Lebenslauf und soziale Differenzierung. In Sozialgeschichte der DDR, eds. H. Kaelble, J. Kocka \& H. Zwahr, 31-62. Stuttgart: Klett-Cotta.

Larner, W. (2000) Neo-liberalism: Policy, ideology, governmentality. Studies in political economy, 63.

Leonard, M. (1998) The long-term unemployed, informal economic activity and the Eunderclass $\uparrow$ in Belfast: Rejecting or reinstating the work ethic? International Journal of Urban and Regional Research 22, 42-59.

Lüdtke, A. 1994. Helden der Arbeit - Mühen beim Arbeiten. Zur mißsmutigen Loyalität von Industriearbeitern in der DDR In Sozialgeschichte der DDR, eds. H. Kaelble, J. Kocka \& H. Zwahr, 188-213. Stuttgart: Klett-Cotta.

Ludwig-Mayerhofer, W. \& A. Wroblewski (2004) Eppur Si Muove? Activation policies in Austria and Germany. European Societies, 6, 485-509. 
MacLeavy, J. (2008) Neoliberalising subjects: The legacy of New Labour's construction of social exclusion in local governance. Geoforum, 39, 1657-1666.

Matejskova, T. (forthcoming) The Unbearable Closeness of the East: Embodied MicroEconomies of Difference, Belonging and Intersecting Marginalities in PostSocialist Berlin Urban Geography.

McDowell, L. 2003. Redundant Masculinities: Employment Change and White Working Class Youth Malden, MA: Wiley-Blackwell.

Mitchell, K. 2004. Crossing the Neoliberal Line: Pacific Rim Migration and the Metropolis. . Philadelphia, PA: Temple University Press.

Nevins, J. (2007) Dying for a cup of coffee? Migrant deaths in the US-Mexico border region in a neoliberal age. Geopolitics, 12, 228-247.

Peck, J. 2001. Workfare states. New York: Guilford Press.

Peck, J. \& N. Theodore (2000) Beyond'employability'. Cambridge Journal of Economics, 24, 729-749.

Pfetsch, B. 1999. In Russia we were Germans, and now we are Russians" dilemmas of identity formation and communication among German-Russian Aussiedler. In Discussion Paper FS III 99-103. . Wissenschaftszentrum Berlin.

Phillips, D. (2006 ) Parallel lives? Challenging discourses of British Muslim selfsegregation. Environment and planning. D, Society \& space 24 25-40.

Phillips, D., C. Davis \& P. Ratcliffe (2007) British Asian narratives of urban space. Transactions of Institute British Geography, 32, 217-234.

Pratt, A. C. \& H. Jarvis (2006) Bringing it all back home: The extensification and 'overflowing' of work. The case of San Francisco's new media households. . Geoforum, 37, 331-339.

Rose, N. 1999. Powers of Freedom: Reframing Political Thought. Cambridge: Cambridge University Press.

Round, J. \& C. Williams (2010) Coping with the social costs of 'transition': Everyday life in post-Soviet Russia and Ukraine. European Urban And Regional Studies, 17, 183-196.

Schinkel, W. \& F. van Houdt (2010) The double helix of cultural assimilationism and neo-liberalism: citizenship in contemporary governmentality. The British Journal of Sociology, 61, 696-714.

Smith, A. (2000) Employment restructuring and household survival in 'postcommunist transition': rethinking economic practices in Eastern Europe. Environment and Planning A, 32, 1759 - 1780

--- (2002) Culture/economy and spaces of economic practice: positioning households in post-communism. Transactions of the Institute of British Geographers 27, 232250.

Smith, A. \& A. Stenning (2006) Beyond household economies: articulations and spaces of economic practice in postsocialism. Progress in Human Geography, 30, 190213.

Smith, A., A. Stenning, A. Rochovska \& D. Swiatek (2008) The emergence of a working poor: Labour markets, neoliberalisation and diverse economies in post-socialist cities. Antipode, 40, 283-311.

Sparke, M. B. (2006) A neoliberal nexus: Economy, security and the biopolitics of citizenship on the border. Political Geography, 25, 151-180. 
Stenning, A. (2003) Shaping the economic landscapes of postsocialism? Labour, workplace and community in Nowa Huta, Poland. Antipode, 35, 761-780.

--- (2005a) Post-socialism and the changing geographies of the everyday in Poland. Transactions of the Institute of British Geographers, 30, 113-127.

--- (2005b) Re-placing work: economic transformations and the shape of a community in post-socialist Poland. Work Employment And Society, 19, 235-259.

--- (2008) For working class geographies. Antipode, 40, 9.

Thelen, T. (2011) Shortage, fuzzy property and other dead ends in the anthropological analysis of (post) socialism. Critique Of Anthropology, 31, 43.

Theodore, N. (2007) New Labour at work: long-term unemployment and the geography of opportunity. Cambridge Journal of Economics, 31, 927-939.

Trudeau, D. \& M. Cope (2003) Labor and housing markets as public spaces: 'personal responsibility' and the contradictions of welfare-reform policies. Environment And Planning A, 35, 779-798.

van Hoven, B. (2001) Women at work-experiences and identity in rural East Germany. Area, 33, 38-46.

---. 2004. Women's lives in transition: 'everything gets better but nothing is good'. In East Central Europe and the former Soviet Union: the post-socialist states, eds. M. Bradshaw \& A. Stenning, 161-186. Harlow: Pearson.

Wohlfahrt, N. 2003. The activating state in Germany: Beyond the Hartz Commission. In »From Welfare to Work « Nonprofits and the Workfare State in Berlin and Los Angeles, eds. V. Eick, M. Mayer \& J. Sambale, 12-20. Berlin: John F. KennedyInstitute, Free University.

Yurchak, A. 2005. Everything was forever, until it was no more: The last Soviet generation. Princeton, NJ: Princeton University Press. 


\section{Appendix}

Figure 1: German state's conceptualization of immigrant integration with stable employment in the center

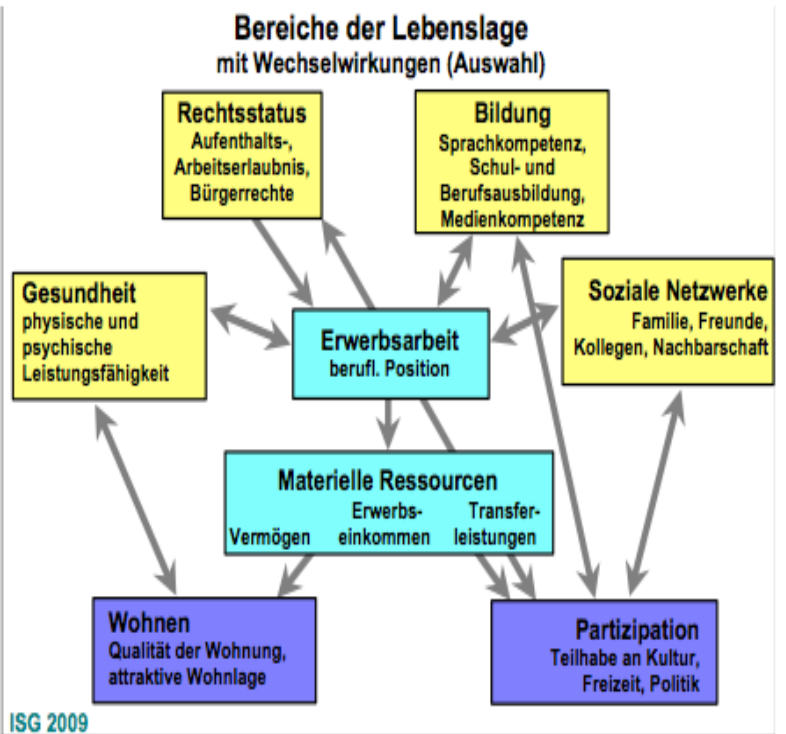

Source: ISG \& WZB (2009). Integration in Deutschland. Erster Integrationsindikatorenbericht: Erprobung des Indikatorensets und Bericht zum bundesweiten Integrationsmonitoring. Berlin, Beauftragte der Bundesregierung für Migration, Flüchtlinge und Integration, p. 22

Figure 2: Dr. Halima Alaiyan works for Germany, one of the posters of the integration policy campaign Diversity as a Chance: Migrants work for Germany

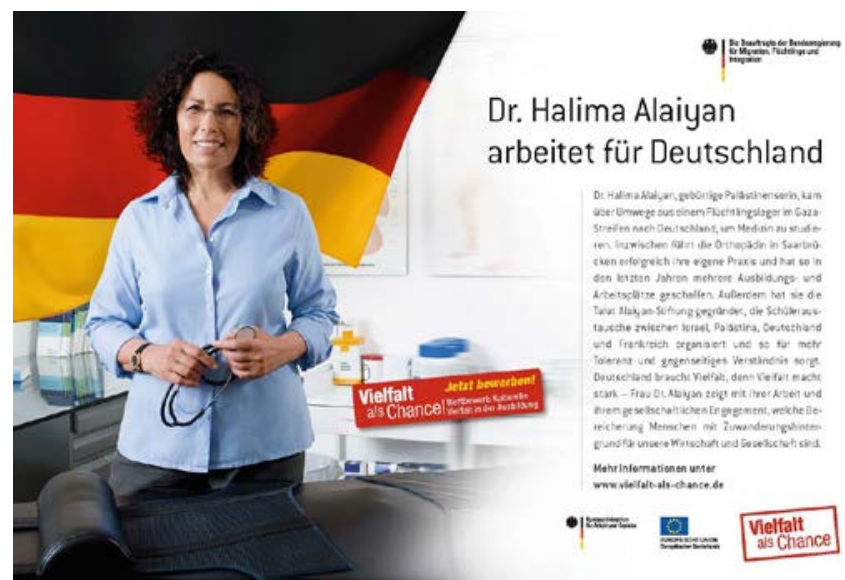

Source: http://www.vielfalt-als-chance.de/index.php?id=278

Figure 3: One of the posters accompanying the National Integration Plan campaign 

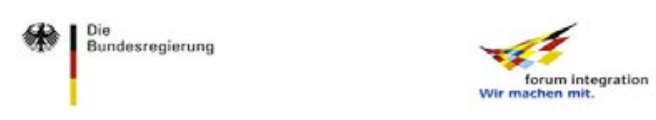

Vertrauen ist keine Frage der Herkunft.

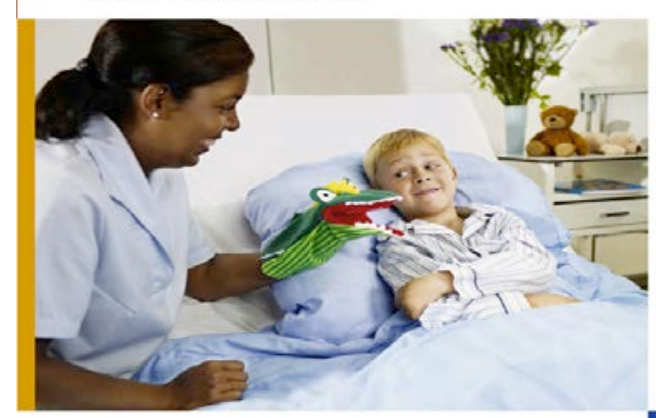

Der Nationale Integrationsplan Neue Wege-Neue Chancen

Source:

http://www.bundesregierung.de/nn_670566/Content/DE/Archiv16/Fotoreihen/2007/2007 -07-13-Kampagne-Integration/kampagne-integration.html?item=7

Figure 3: German state's conceptualization of immigrant integration with stable employment in the center

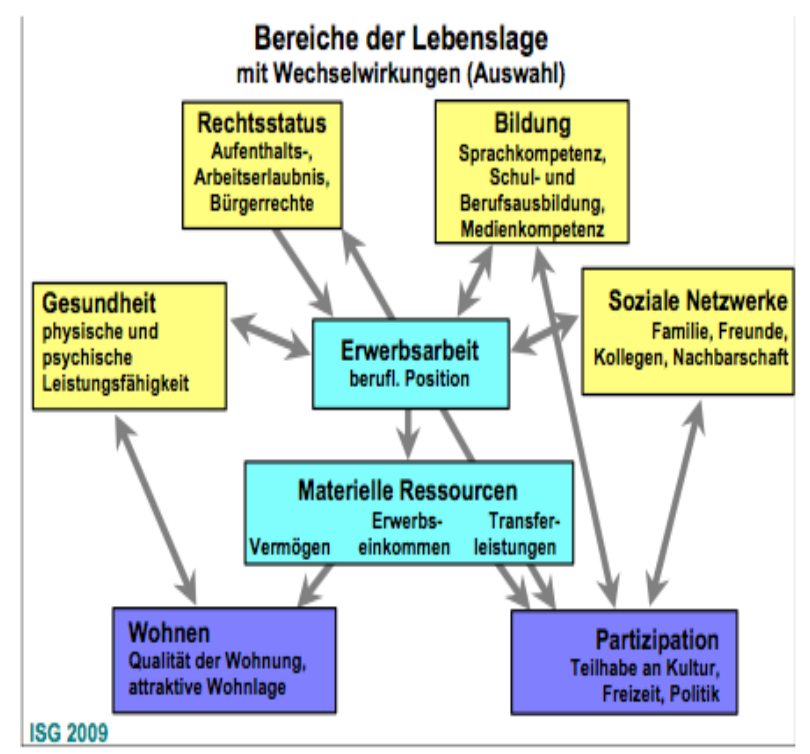

Source: ISG \& WZB (2009). Integration in Deutschland. Erster Integrationsindikatorenbericht: Erprobung des Indikatorensets und Bericht zum bundesweiten Integrationsmonitoring. Berlin, Beauftragte der Bundesregierung für Migration, Flüchtlinge und Integration, p. 22 
